\title{
Phagocytosis and neutrophil extracellular traps
}

\author{
Frank R. DeLeo ${ }^{1^{*}} \quad$ Lee-Ann H. Allen ${ }^{2,3,4 *}$ \\ ${ }^{1}$ Laboratory of Bacteriology, Rocky Mountain Laboratories, National Institute of Allergy and Infectious Diseases, National Institutes of Health, Hamilton, MT, \\ USA \\ ${ }^{2}$ Inflammation Program, Department of Internal Medicine and Department of Microbiology and Immunology, University of Iowa, Iowa City, IA, USA \\ ${ }^{3}$ VA Healthcare System, Iowa City, IA, USA \\ ${ }^{4}$ Department of Molecular Microbiology and Immunology, University of Missouri School of Medicine, Columbia, MO, USA
}

\begin{abstract}
Neutrophils are recruited rapidly to sites of infection in response to host- and/or microbe-derived proinflammatory molecules. At such sites, neutrophils phagocytose microbes and are activated to produce superoxide and other reactive oxygen species (ROS). In addition, neutrophils contain stores of antimicrobial peptides and enzymes that work in concert with ROS to kill ingested microbes. Neutrophils can also release chromosomal DNA bound with antimicrobial peptides and enzymes to form web-like structures known as extracellular traps. Neutrophil extracellular traps (NETs) have been reported to ensnare and kill microbes and are commonly considered to be an important component of innate host defense. Notably, the formation of NETs is most often reported as a cytolytic process. Whereas intraphagosomal killing of microbes sequesters cytotoxic antimicrobial molecules that would otherwise damage host tissues, the formation of NETs and associated extracellular release of these molecules can contribute to host tissue destruction and disease. Here we compare and contrast phagocytosis and NETs in host defense, with emphasis on recent studies of NETs that ultimately underscore the importance of phagocytosis as the primary means by which neutrophils eliminate microbes.
\end{abstract}

\section{Keywords}

Neutrophil, neutrophil extracellular trap, NETs, phagocytosis

\section{Peer Review}

The peer reviewers who approve this article are:

1. Maren von Köckritz-Blickwede, Department of Physiological Chemistry \& Research Center for Emerging Infections and Zoonoses, University of Veterinary Medicine Hannover, Hannover, Germany

Competing interests: No competing interests were disclosed.

2. Marko Radic, Department of Microbiology, Immunology and Biochemistry, University of Tennessee Health Science Center, Memphis, TN, USA

Competing interests: No competing interests were disclosed. 
*Corresponding author: Frank R. DeLeo (frank.deleo@nih.gov); Lee-Ann H. Allen (lee-ann.allen@health.missouri.edu)

Competing interests: The authors declare that they have no competing interests.

Grant information: The authors are supported by the Intramural Research Program, National Institute of Allergy and Infectious Diseases, National Institutes of Health (to Frank R. DeLeo), R01AI119965 (to Lee-Ann H. Allen), and a Department of Veteran's Affairs VA Merit Review Grant I01BX002108 (to Lee-Ann H. Allen).

The funders had no role in study design, data collection and analysis, decision to publish, or preparation of the manuscript.

Copyright: (C) 2020 DeLeo FR et al. This is an open access article distributed under the terms of the Creative Commons Attribution License, which permits unrestricted use, distribution, and reproduction in any medium, provided the original work is properly cited.

How to cite this article: DeLeo FR and Allen LAH. Phagocytosis and neutrophil extracellular traps. Faculty Reviews 2020 9:(25) https://doi . org/10.12703/r/9-25

Published: 21 Dec 2020, Faculty Reviews 9:(25) https://doi.org/10.12703/r/9-25 


\section{Introduction}

Neutrophils are the most abundant leukocytes in human blood, and their central role in innate defense against infection is unequivocal. The processes that recruit neutrophils to sites of microbe invasion, phagocytosis, and coupling of the engulfment process to rapid deployment of oxygen-dependent and oxygen-independent mechanisms for efficient microbe killing and digestion have been studied extensively. Many fundamental insights into these neutrophil processes have arisen from studies of human patients and bacterial and fungal pathogens to inhibit or coopt these defense processes to evade elimination while also causing tissue destruction and disease.

\section{Phagocytosis, phagocytic killing, and neutrophil extracellular traps}

Phagocytosis is a specialized form of receptor-mediated endocytosis that is utilized by neutrophils and macrophages to ingest particles and microbes that are at least 0.5 microns in size $^{1}$. The list of phagocytic receptors continues to grow and includes molecules that bind directly to microbes such CEACAMs, lectins, and integrins as well as receptors that engage microbes opsonized with $\mathrm{IgG}$ or complement fragments ${ }^{2}$. In all cases, signaling downstream of these receptors triggers local actin polymerization that is essential for extension of membrane pseudopodia around the microbe and its internalization.

A distinguishing feature of neutrophils is the fact that phagocytic receptor signaling also elicits rapid deployment of oxidative and non-oxidative host defense mechanisms via simultaneous assembly and activation of the Nox2-containing NADPH oxidase complex and mobilization of specific and azurophilic granules. As a result, phagosome-granule fusion and the production of superoxide anions and other toxic ROS is typically apparent within 60 seconds of particle or microbe binding $^{3-5}$. The speed and efficiency of this process creates a highly lethal milieu in the phagosome lumen that consists of oxidants, cationic antimicrobial peptides, iron binding proteins, and enzymes such as elastase and myeloperoxidase (MPO). The formation of such an environment is in keeping with the ability of neutrophils to kill the majority of ingested microbes within 30 minutes $^{6-8}$. By contrast, phagosome maturation in macrophages is relatively slow and consists of incremental modification of nascent phagosomes via sequential interaction with early endosomes, late endosomes, and lysosomes ${ }^{9}$.

The importance of NADPH oxidase-derived ROS to microbe killing is exemplified by the life-threatening infections that arise in patients who have inherited mutations in genes that encode subunits of this enzyme complex ${ }^{10}$. Pathogens that evade killing by neutrophils inhibit or evade toxic ROS and achieve this by inhibiting NADPH oxidase targeting, assembly, or activity $^{11-14}$. Less is known about the mechanisms that control oxygen-independent defense mechanisms, including granule targeting and fusion, but recent data indicate that distinct Rab27-independent and -dependent mechanisms control azurophilic granule fusion with phagosomes and the plasma membrane, respectively ${ }^{15}$. Additional insight will likely be gleaned from further studies of pathogens that manipulate phagosome fusion with specific and/or azurophilic granules as part of their virulence strategies ${ }^{2}$.

The discovery of neutrophil extracellular traps (NETs) suggested the existence of an additional mechanism that allows neutrophils to trap and/or kill extracellular microbes ${ }^{16}$. In a landmark study, Brinkmann et al. reported that some activated neutrophils release decondensed chromatin fibers as web-like structures to which cationic neutrophil proteins such as elastase, histones, and MPO are bound ${ }^{16}$. These structures-aptly named NETs - can ensnare and kill microorganisms. Subsequent work by the same group of researchers reported a mechanism for the formation of NETs that requires ROS and, more notably, is a cytolytic process ${ }^{17}$. The formation of NETs that results from neutrophil lysis was proposed as a novel cell death program ultimately termed NETosis ${ }^{17,18}$. The formation of NETs and NETosis have often been used as synonymous terms for years, but whether the formation of NETs is always a result of the cytolytic process described as NETosis has been called into question ${ }^{19,20}$. Indeed, NETs can form from viable neutrophils ${ }^{21-23}$ or from neutrophils that have undergone non-specific lysis ${ }^{24}$. Thus, there is reasonable agreement in the field that the term "NETosis" should not be used to describe the formation of NETs unless a specific cell death mechanism is known ${ }^{19,25,26}$.

NETs have been studied extensively since the report by Brinkmann et al., and it is clear they can contribute to host defense. For example, Urban et al. ${ }^{27}$ and Branzk et al. ${ }^{28}$ reported that NETs are important for host defense against microbes that cannot be phagocytosed, such as fungi in hyphal form. More recently, Thanabalasuriar et al. demonstrated that NETs prevent dissemination of Pseudomonas aeruginosa from biofilms in a mouse infection model ${ }^{29}$. These roles for NETs in host defense are important and complementary to those of phagocytosis. However, the misconception that NETs are a primary means by which neutrophils kill microorganisms has become seemingly pervasive outside of the field of phagocyte biology. Here we compare and contrast phagocytosis and the formation of NETs (and outcomes associated with each process) as components of host defense.

\section{Physical sequestration of microbes following phagocytosis}

There is no question that the ability of neutrophils to sequester microbes within an enclosed phagocytic vacuole (phagosome) is important for host defense. Ingested microbes can no longer disseminate freely, and molecules normally shed or secreted from pathogenic microbes are contained within phagosomes and thus unable to contribute to disease. By comparison, NETs ensnare microorganisms, but surface binding to a DNA scaffold is not likely to prevent dissemination fully. Moreover, NET-bound microbes are still able to release molecules such as bacterial endotoxins that can be detrimental. These latter points notwithstanding, studies by Branzk et al. and 
Thanabalasuriar et al. underscore the important role played by NETs if phagocytosis is not possible (because particles are too large). Branzk et al. also found that when phagocytosis occurs, it inhibits the formation of NETs via a mechanism involving sequestration of neutrophil elastase ${ }^{28}$. This intriguing finding provides support to the idea that phagocytosis and NETs have specific roles in host defense.

\section{High intraphagosomal concentration of microbicides}

Few microorganisms have the ability to survive following phagocytosis by neutrophils. This is because intraphagosomal concentrations of neutrophil ROS and antimicrobial peptides are extraordinarily high, as intraphagosomal volume is limited (estimated at $1.2 \mu \mathrm{m}^{3}$ for bacterial phagosomes) ) $^{30,31}$. For example, Winterbourn et al. estimated the initial rate of superoxide generation as $5.2 \mathrm{mM} / \mathrm{second}$ and the intraphagosomal concentration of MPO as $\sim 1 \mathrm{mM}^{31}$. Based on these estimates, hypochlorous acid $(\mathrm{HOCl})$, commonly known as the active ingredient in household bleach, is produced at $134 \mathrm{mM} /$ minute. The granule protein concentration in the neutrophil phagosome has been estimated to be as high as $200 \mathrm{mg} / \mathrm{mL}^{30}$. Although MPO and elastase, components of neutrophil azurophilic granules, are hallmark features of NETs, the amount present on an extracellular DNA scaffold is likely far less than that present in phagosomes. Moreover, the concentration of ROS produced within phagosomes is simply not possible on or near NETs, as intact and viable neutrophils are needed to produce ROS, the half-life of these molecules is limited, and they diffuse readily. Therefore, compared with the microbicidal processes that occur within phagosomes (following phagocytosis), NETs have far less capacity to kill microorganisms.

\section{Nonphlogistic removal of apoptotic neutrophils}

ROS and antimicrobial enzymes contained within neutrophil granules are not microbe specific and can also cause non-specific damage to host cells and tissues if they are released by exocytosis or following cell lysis ${ }^{32-34}$. Extracellular release of these toxic agents by neutrophils contributes significantly to many human inflammatory diseases. Therefore, it is not surprising that neutrophil lifespan and antimicrobial functions are highly regulated. Human neutrophils are terminally differentiated cells that undergo apoptosis constitutively at the end of their lifespan ${ }^{35}$. As neutrophils undergo apoptosis, they lose functional capacity, as indicated by defects in chemotaxis, phagocytosis, degranulation, and the ability to produce superoxide in response to certain stimuli ${ }^{36}$. Importantly, apoptotic neutrophils remain intact and are ingested by mononuclear phagocytes in a non-inflammatory process known as efferocytosis ${ }^{35}$. Removal of apoptotic neutrophils helps maintain immune system homeostasis and is key to resolution of the inflammatory response. This highly regulated process prevents host exposure to components of lysed neutrophils. Therefore, it could be argued that the formation of NETs by cytolysis is an incidental phenomenon that results from necrotic lysis rather than a unique type of cell death. This notion is gaining support among neutrophil biologists and cell death experts ${ }^{19,25}$.

\section{Noncytolytic versus cytolytic processes for the formation of NETs}

The formation of NETs was described initially as a cytolytic process that culminates in the loss of plasma membrane integrity and release of cellular contents, most notably nuclear DNA, histones, and components of cytoplasmic granules, into the extracellular milieu ${ }^{16,17}$. Indeed, the majority of studies of NETs or their components either directly demonstrate or infer lysis of neutrophils. By comparison, Yousefi and colleagues first reported that extracellular traps form from mitochondrial DNA released from viable eosinophils ${ }^{37}$. This finding has since been extended to include neutrophils ${ }^{21}$ and basophils ${ }^{38}$. The formation of NETs from viable neutrophils is a noncytolytic process and is therefore compatible with the regulated turnover of neutrophils described above. More notably, such a process has the potential to function in concert with phagocytosis, as described above for microbes that cannot be ingested.

\section{NETs and human disease}

Inasmuch as neutrophils are abundant leukocytes and have tremendous capacity for cytotoxicity, it is not unexpected that many diseases are associated with NETs. Although there are caveats with associating NETs and human disease, the sheer number of recent findings in this area underscores the importance of strictly regulated neutrophil activation and turnover (safe removal) to health and homeostasis. For example, NETs have been associated with multiple types of cancer and cancer metastasis $^{39,40}$, including breast cancer ${ }^{41}$, hepatocellular carcinoma ${ }^{42}$, lung cancer ${ }^{43}$, ovarian cancer $^{44}$, oral squamous cell carcinoma ${ }^{45}$, pancreatic cancer ${ }^{46}$, and thyroid cancer ${ }^{47}$. NETs have been implicated in autoimmune disorders such as lupus erythematosus ${ }^{48-51}$ and in the development of thrombosis ${ }^{52-54}$ and can contribute to the severity of sepsis ${ }^{55,56}$. Cell-free or extracellular DNA associated with elastase, MPO, and/or citrullinated histones has been associated with numerous respiratory diseases. NETs or NET components have been found in sputum from individuals with chronic obstructive pulmonary disease ${ }^{57}$ and severe asthma $^{58}$, plasma from patients with severe influenza A virus infection ${ }^{59}$, bronchoalveolar lavage fluid from patients with ventilator-associated pneumonia ${ }^{60}$, and in plasma from patients with acute respiratory distress syndrome ${ }^{61}$. Most recently, NETs have been associated with severe COVID-1962,63.

Collectively, these data further support the idea that nonphlogistic turnover of neutrophils is essential to human health. In contrast to NETs, neutrophil phagocytosis is not associated directly with severe pathologies or disease.

\section{Conclusion}

The idea that neutrophils utilize NETs extensively to eradicate microbes or that NETs are employed for host defense more prominently than phagocytosis has become increasingly pervasive outside of the field of phagocyte biology. Although a significant body of work supports the notion that NETs can contribute to host defense, the relative contribution of NETs to human host defense in vivo remains largely unknown. This 
issue is difficult to address, in part because the formation of NETs and neutrophil lysis can be synonymous. Identification of cell-free/extracellular DNA associated with citrullinated histones and/or neutrophil granule proteins is consistent with neutrophil lysis in vivo, a phenomenon linked to tissue destruction and disease. Indeed, the vast majority of studies published on the topic of NETs within the past two years underscore the role of NETs in disease. These data are consistent with the long-held tenet that uncontrolled release of neutrophil components, as occurs in cytolysis, is detrimental to health and exacerbates disease. Notably, the host immune system has evolved numerous tightly controlled mechanisms to prevent cytolysis, which implies that the formation of NETs via cell lysis is incidental, as is the contribution of such NETs to host defense.

Here we considered phagocytosis and NETs as components of host defense. Based on an assessment of historic and recently published studies and established paradigms, it seems clear that phagocytosis coupled to rapid phagosome-granule fusion and ROS production remains the primary means by which neutrophils eliminate invading microbes. More work is needed to determine the relative contribution of NETs and other lytic cell death mechanisms to host defense in vivo.
1. Griffin FM Jr, Griffin JA, Leider JE, et al.: Studies on the mechanism of phagocytosis. I. Requirements for circumferential attachment of particlebound ligands to specific receptors on the macrophage plasma membrane. J Exp Med. 1975; 142(5): 1263-82.

PubMed Abstract | Publisher Full Text | Free Full Text

2. Allen LAH, Criss AK: Cell intrinsic functions of neutrophils and their manipulation by pathogens. Curr Opin Immunol. 2019; 60: 124-9. PubMed Abstract | Publisher Full Text | Free Full Text

3. Nordenfelt $\mathrm{P}, \mathrm{Tapper} \mathrm{H}$ : Phagosome dynamics during phagocytosis by neutrophils. J Leukoc Biol. 2011; 90(2): 271-84. PubMed Abstract | Publisher Full Text

4. Allen LA, DeLeo FR, Gallois A, et al.: Transient association of the nicotinamide adenine dinucleotide phosphate oxidase subunits p47phox and p67phox with phagosomes in neutrophils from patients with $X$-linked chronic granulomatous disease. Blood. 1999; 93(10): 3521-30 PubMed Abstract | Publisher Full Text

5. DeLeo FR, Allen LAH, Apicella M, et al:: NADPH oxidase activation and assembly during phagocytosis. J Immunol. 1999; 163(12): 6732-40. PubMed Abstract

6. Segal AW: How neutrophils kill microbes. Annu Rev Immunol. 2005; 23: 197-223. PubMed Abstract | Publisher Full Text | Free Full Text

7. Hampton MB, Vissers MC, Winterbourn CC: A single assay for measuring the rates of phagocytosis and bacterial killing by neutrophils. J Leukoc Biol. 1994; 55(2): 147-52.

PubMed Abstract | Publisher Full Text

8. Kobayashi SD, Braughton KR, Whitney AR, et al:: Bacterial pathogens modulate an apoptosis differentiation program in human neutrophils. Proc Natl Acad Sci U S A. 2003; 100(19): 10948-53.

PubMed Abstract | Publisher Full Text | Free Full Text Faculty Opinions Recommendation

9. Flannagan RS, Cosío G, Grinstein S: Antimicrobial mechanisms of phagocytes and bacterial evasion strategies. Nat Rev Microbiol. 2009; 7(5): 355-66. PubMed Abstract | Publisher Full Text

10. Nauseef WM, Clark RA: Intersecting stories of the phagocyte NADPH oxidase and chronic granulomatous disease. Methods Mol Biol. 2019; 1982: 3-16.

PubMed Abstract | Publisher Full Text | Faculty Opinions Recommendation

11. Allen $L A H, M c C a f f r e y ~ R L:$ To activate or not to activate: Distinct strategies used by Helicobacter pylori and Francisella tularensis to modulate the NADPH oxidase and survive in human neutrophils. Immunol Rev. 2007; 219: 103-17. PubMed Abstract | Publisher Full Text

12. IJdo JW, Mueller AC: Neutrophil NADPH oxidase is reduced at the Anaplasma phagocytophilum phagosome. Infect Immun. 2004; 72(9): 5392-401. PubMed Abstract | Publisher Full Text | Free Full Text

13. Edmisson JS, Tian S, Armstrong CL, et al:: Filifactor alocis modulates human neutrophil antimicrobial functional responses. Cell Microbiol. 2018; 20(6): e12829.

PubMed Abstract | Publisher Full Text | Free Full Text Faculty Opinions Recommendation

14. Smirnov A, Daily KP, Criss AK: Assembly of NADPH oxidase in human neutrophils is modulated by the opacity-associated protein expression state of Neisseria gonorrhoeae. Infect Immun. 2014; 82(3): 1036-44. PubMed Abstract | Publisher Full Text | Free Full Text

15. Johnson JL, Brzezinska AA, Tolmachova T, et al.: Rab27a and Rab27b regulate neutrophil azurophilic granule exocytosis and NADPH oxidase activity by independent mechanisms. Traffic. 2010; 11(4): 533-47. PubMed Abstract | Publisher Full Text | Free Full Text

16. Brinkmann V, Reichard U, Goosmann C, et al:: Neutrophil extracellular traps kill bacteria. Science. 2004; 303(5663): 1532-5. PubMed Abstract | Publisher Full Text | Faculty Opinions Recommendation

17. Fuchs TA, Abed U, Goosmann C, et al.: Novel cell death program leads to neutrophil extracellular traps. J Cell Biol. 2007; 176(2): 231-41. PubMed Abstract | Publisher Full Text | Free Full Text | Faculty Opinions Recommendation

18. Steinberg BE, Grinstein S: Unconventional roles of the NADPH oxidase: Signaling, ion homeostasis, and cell death. SCi STKE. 2007; 2007(379): pe11. PubMed Abstract | Publisher Full Text

19. Yousefi S, Stojkov D, Germic N, et al.: Untangling "NETosis" from NETs. Eur J Immunol. 2019; 49(2): 221-7.

PubMed Abstract | Publisher Full Text | Faculty Opinions Recommendation

20. Yipp BG, Kubes P: NETosis: How vital is it? Blood. 2013; 122(16): 2784-94. PubMed Abstract | Publisher Full Text

21. Yousefi S, Mihalache $C$, Kozlowski E, et al: Viable neutrophils release mitochondrial DNA to form neutrophil extracellular traps. Cell Death Differ. 2009; 16(11): 1438-44.

PubMed Abstract | Publisher Full Text

22. Pilsczek FH, Salina D, Poon KKH, et al:: A novel mechanism of rapid nuclear neutrophil extracellular trap formation in response to Staphylococcus aureus. $J$ Immunol. 2010; 185(12): 7413-25. PubMed Abstract | Publisher Full Text

23. Yipp BG, Petri B, Salina D, et al:: Infection-induced NETosis is a dynamic process involving neutrophil multitasking in vivo. Nat Med. 2012; 18(9): 1386-93.

PubMed Abstract | Publisher Full Text | Free Full Text | Faculty Opinions Recommendation

24. Malachowa N, Kobayashi SD, Freedman B, et al.: Staphylococcus aureus leukotoxin GH promotes formation of neutrophil extracellular traps. J Immunol. 2013; 191(12): 6022-9. PubMed Abstract | Publisher Full Text | Free Full Text

25. Boeltz S, Amini P, Anders HJ, et al.: To NET or not to NET:current opinions and state of the science regarding the formation of neutrophil extracellular traps. Cell Death Differ. 2019; 26(3): 395-408. PubMed Abstract | Publisher Full Text | Free Full Text | Faculty Opinions Recommendation

26. Galluzzi L, Vitale I, Aaronson SA, et al:: Molecular mechanisms of cell death: Recommendations of the Nomenclature Committee on Cell Death 2018. Cell Death Differ. 2018; 25(3): 486-541.

PubMed Abstract | Publisher Full Text | Free Full Text | Faculty Opinions Recommendation 
27. Urban CF, Reichard U, Brinkmann V, et al.: Neutrophil extracellular traps capture and kill Candida albicans yeast and hyphal forms. Cell Microbiol. 2006; 8(4): 668-76.

PubMed Abstract | Publisher Full Text

28. Branzk N, Lubojemska A, Hardison SE, et al:: Neutrophils sense microbe size and selectively release neutrophil extracellular traps in response to large pathogens. Nat Immunol. 2014; 15(11): 1017-25. PubMed Abstract | Publisher Full Text | Free Full Text | Faculty Opinions Recommendation

29. Thanabalasuriar A, Scott BNV, Peiseler M, et al.: Neutrophil extracellular traps confine Pseudomonas aeruginosa ocular biofilms and restrict brain invasion. Cell Host Microbe. 2019; 25(4): 526-536.e4. PubMed Abstract | Publisher Full Text | Free Full Text Faculty Opinions Recommendation

30. Winterbourn CC, Kettle AJ: Redox reactions and microbial killing in the neutrophil phagosome. Antioxid Redox Signal. 2013; 18(6): 642-60. PubMed Abstract | Publisher Full Text

31. Winterbourn CC, Hampton MB, Livesey JH, et al.: Modeling the reactions of superoxide and myeloperoxidase in the neutrophil phagosome: implications for microbial killing. J Biol Chem. 2006; 281(52): 39860-9. PubMed Abstract | Publisher Full Text

32. Henson PM, Johnston RB Jr: Tissue injury in inflammation. Oxidants, proteinases, and cationic proteins. J Clin Invest. 1987; 79(3): 669-74. PubMed Abstract | Publisher Full Text | Free Full Text

33. Brazil JC, Parkos CA: Pathobiology of neutrophil-epithelial interactions. Immunol Rev. 2016; 273(1): 94-111.

PubMed Abstract | Publisher Full Text | Free Full Text

34. Weiss SJ: Tissue destruction by neutrophils. N Engl J Med. 1989; 320(6) 365-76.

PubMed Abstract | Publisher Full Text

35. Savill JS, Wyllie AH, Henson JE, et al.: Macrophage phagocytosis of aging neutrophils in inflammation. Programmed cell death in the neutrophil leads to its recognition by macrophages. J Clin Invest. 1989; 83(3): 865-75. PubMed Abstract | Publisher Full Text | Free Full Text

36. Whyte MK, Meagher LC, MacDermot J, et al.: Impairment of function in aging neutrophils is associated with apoptosis. J Immunol. 1993; 150(11): 5124-34. PubMed Abstract

37. Yousefi S, Gold JA, Andina N, et al:: Catapult-like release of mitochondrial DNA by eosinophils contributes to antibacterial defense. Nat Med. 2008; 14(9): 949-53.

PubMed Abstract | Publisher Full Text | Faculty Opinions Recommendation

38. Morshed M, Hlushchuk R, Simon D, et al.: NADPH oxidase-independent formation of extracellular DNA traps by basophils. J Immunol. 2014; 192(11): 5314-23.

PubMed Abstract | Publisher Full Text

39. Grilz E, Mauracher LM, Posch F, et al:: Citrullinated histone H3, a biomarker for neutrophil extracellular trap formation, predicts the risk of mortality in patients with cancer Br J Haematol. 2019; 186(2): 311-20.

PubMed Abstract | Publisher Full Text | Free Full Text | Faculty Opinions Recommendation

40. Rayes RF, Mouhanna JG, Nicolau I, et al:: Primary tumors induce neutrophil extracellular traps with targetable metastasis promoting effects. JCl Insight. 2019; 5(16): e128008.

PubMed Abstract | Publisher Full Text | Free Full Text |

Faculty Opinions Recommendation

41. Mouchemore KA, Anderson RL, Hamilton JA: Neutrophils, G-CSF and their contribution to breast cancer metastasis. FEBS J. 2018; 285(4): 665-79. PubMed Abstract | Publisher Full Text | Faculty Opinions Recommendation

42. Vun der Windt DJ, Sud V, Zhang $\mathrm{H}$, et al.: Neutrophil extracellular traps promote inflammation and development of hepatocellular carcinoma in nonalcoholic steatohepatitis. Hepatology. 2018; 68(4): 1347-60. PubMed Abstract | Publisher Full Text | Free Full Text | Faculty Opinions Recommendation

43. Inoue M, Nakashima R, Enomoto M, et al.: Plasma redox imbalance caused by albumin oxidation promotes lung-predominant NETosis and pulmonary cancer metastasis. Nat Commun. 2018; 9(1): 5116. PubMed Abstract | Publisher Full Text | Free Full Text | Faculty Opinions Recommendation

44. Lee W, Ko SY, Mohamed MS, et al.: Neutrophils facilitate ovarian cancer premetastatic niche formation in the omentum. J Exp Med. 2019; 216(1): premetasta 94 . PubMed Abstract | Publisher Full Text | Free Full Text | Faculty Opinions Recommendation

45. Li B, Liu Y, Hu T, et al.: Neutrophil extracellular traps enhance procoagulant activity in patients with oral squamous cell carcinoma. J Cancer Res Clin Oncol. 2019; 145(7): 1695-707.

PubMed Abstract | Publisher Full Text | Faculty Opinions Recommendation
46. Jung HS, Gu J, Kim JE, et al:: Cancer cell-induced neutrophil extracellular traps promote both hypercoagulability and cancer progression. PLOS One. 2019; 14(4): e0216055.

PubMed Abstract | Publisher Full Text | Free Full Text |

Faculty Opinions Recommendation

47. Cristinziano L, Modestino L, Loffredo S, et al:: Anaplastic thyroid cancer cells induce the release of mitochondrial extracellular DNA traps by viable neutrophils. J Immunol. 2020; 204(5): 1362-72.

PubMed Abstract | Publisher Full Text | Faculty Opinions Recommendation

48. van der Linden M, van den Hoogen LL, Westerlaken GHA, et al.: Neutrophil extracellular trap release is associated with antinuclear antibodies in systemic lupus erythematosus and anti-phospholipid syndrome. Rheumatology (Oxford). 2018; 57(7): 1228-34.

PubMed Abstract | Publisher Full Text | Faculty Opinions Recommendation

49. Liu Y, Lightfoot YL, Seto N, et al.: Peptidylarginine deiminases 2 and 4 modulate innate and adaptive immune responses in TLR-7-dependent lupus. JCl Insight. 2018; 3(23): e124729.

PubMed Abstract | Publisher Full Text | Free Full Text |

Faculty Opinions Recommendation

50. Odqvist L, Jevnikar Z, Riise R, et al.: Genetic variations in A20 DUB domain provide a genetic link to citrullination and neutrophil extracellular traps in systemic lupus erythematosus. Ann Rheum Dis. 2019; 78(10): 1363-70. PubMed Abstract | Publisher Full Text | Free Full Text | Faculty Opinions Recommendation

51. Mistry P, Nakabo S, O'Neil L, et al.: Transcriptomic, epigenetic, and functional analyses implicate neutrophil diversity in the pathogenesis of systemic lupus erythematosus. Proc Natl Acad Sci U S A. 2019; 116(50): 25222-8.

PubMed Abstract | Publisher Full Text | Free Full Text | Faculty Opinions Recommendation

52. Nakazawa D, Desai J, Steiger S, et al:: Activated platelets induce MLKLdriven neutrophil necroptosis and release of neutrophil extracellular traps in venous thrombosis. Cell Death Discov. 2018; 4: 6. PubMed Abstract | Publisher Full Text | Free Full Text | Faculty Opinions Recommendation

53. Gollomp K, Kim M, Johnston I, et al:: Neutrophil accumulation and NET release contribute to thrombosis in HIT. JCI Insight. 2018; 3(18): e99445. PubMed Abstract | Publisher Full Text | Free Full Text | Faculty Opinions Recommendation

54. Perdomo J, Leung HHL, Ahmadi Z, et al:: Neutrophil activation and NETosis are the major drivers of thrombosis in heparin-induced thrombocytopenia. Nat Commun. 2019; 10(1): 1322.

PubMed Abstract | Publisher Full Text | Free Full Text | Faculty Opinions Recommendation

55. Colón DF, Wanderley CW, Franchin M, et al:: Neutrophil extracellular traps (NETs) exacerbate severity of infant sepsis. Crit Care. 2019; 23(1): 113. PubMed Abstract | Publisher Full Text | Free Full Text | Faculty Opinions Recommendation

56. Barbosa da Cruz D, Helms J, Aquino LR, et al.: DNA-bound elastase of neutrophil extracellular traps degrades plasminogen, reduces plasmin formation, and decreases fibrinolysis: proof of concept in septic shock plasma. FASEB J. 2019; 33(12): 14270-80.

PubMed Abstract | Publisher Full Text | Faculty Opinions Recommendation

57. Dicker AJ, Crichton ML, Pumphrey EG, et al:: Neutrophil extracellular traps are associated with disease severity and microbiota diversity in patients with chronic obstructive pulmonary disease. J Allergy Clin Immunol. 2018; 141(1): 117-27.

PubMed Abstract | Publisher Full Text | Free Full Text |

Faculty Opinions Recommendation

58. Lachowicz-Scroggins ME, Dunican EM, Charbit AR, et al.: Extracellular DNA, neutrophil extracellular traps, and inflammasome activation in severe asthma. Am J Respir Crit Care Med. 2019; 199(9): 1076-85. PubMed Abstract | Publisher Full Text | Free Full Text | Faculty Opinions Recommendation

59. Zhu L, Liu L, Zhang Y, et al.: High level of neutrophil extracellular traps correlates with poor prognosis of severe influenza A infection. J Infect Dis. 2018; 217(3): 428-37.

PubMed Abstract | Publisher Full Text | Faculty Opinions Recommendation

60. Mikacenic C, Moore R, Dmyterko V, et al:: Neutrophil extracellular traps (NETs) are increased in the alveolar spaces of patients with ventilatorassociated pneumonia. Crit Care. 2018; 22(1): 358. PubMed Abstract | Publisher Full Text | Free Full Text | Faculty Opinions Recommendation

61. Lefrançais E, Mallavia B, Zhuo H, et al.: Maladaptive role of neutrophil 
extracellular traps in pathogen-induced lung injury. JCI Insight. 2018; 3(3) e98178.

PubMed Abstract | Publisher Full Text | Free Full Text |

Faculty Opinions Recommendation

62. Barnes BJ, Adrover JM, Baxter-Stoltzfus A, et al:: Targeting potential drivers of COVID-19: Neutrophil extracellular traps. J Exp Med. 2020; 217(6): e20200652.

PubMed Abstract | Publisher Full Text | Free Full Text |

Faculty Opinions Recommendation

63. Zuo Y, Zuo M, Yalavarthi S, et al.: Neutrophil extracellular traps and thrombosis in COVID-19. medRxiv. 2020; 2020.04.30.20086736.

PubMed Abstract | Publisher Full Text | Free Full Text 